\title{
PERCEPTION OF BUSINESS ENTITIES TOWARDS DIGITIZATION OF TAX ADMINISTRATION IN THE CZECH REPUBLIC
}

\author{
Šárka Sobotovičová1, Beata Blechová
}

\footnotetext{
1 Silesian University in Opava, School of Business Administration in Karviná, Department of Finance and Accounting, Czech Republic, ORCID: 0000-0001-9665-2043, sobotovicova@opf.slu.cz;

2 Silesian University in Opava, School of Business Administration in Karviná, Department of Finance and Accounting, Czech Republic, ORCID: 0000-0003-3629-4066, blechova@opf.slu.cz.
}

\begin{abstract}
The digital transformation of all areas of government is one of the European Union priorities. The motivation for our research was the fact that when it comes to the evaluation of Digital Public Services, the Czech Republic ranks below the EU countries average. This article discusses the development of electronic filings for the Financial Administration in the Czech Republic. It started with a critical literature review of relevant sources. Subsequently, a research was conducted with 644 respondents in the form of a questionnaire survey. Based on the primary research, opinions on the digitization of financial administration, including the benefits and disadvantages it brings to them, was verified with entrepreneurs. The survey data was evaluated using a non-parametric test in SPSS Statistics. Following an empirical survey, it was found that the majority of respondents perceive electronic filings in a positive way. The most common form of electronic filing is through data boxes, which have been in use in the Czech Republic since 2009. Less than half of the respondents had some problems related to the introduction of electronic filings. Some of the most common issues mentioned included the familiarization with the requirements associated with the electronic filings and learning to use the program in general. With the majority of respondents, accountants are responsible for interaction with the Financial Administration. Based on the respondents' perception, the saving of time was identified as the most significant benefit, followed by the availability of information and error checks; saving of costs was the last. The respondents evaluate electronic communication as more flexible, practical and easier.
\end{abstract}

Keywords: Digitization, Financial administration, Electronic filing, Electronic communication.

JEL Classification: H20, G38, M10.

APA Style Citation: Sobotovičová, Š., \& Blechová, B. (2021). Perception of Business Entities towards Digitization of Tax Administration in the Czech Republic. E\&M Economics and Management, 24(3), 208-223. https://doi.org/10.15240/tul/001/2021-3-012

\section{Introduction}

One of the thematic objectives of the European Union cohesion policy for 20142020 is to improve access to information and communication technologies and increase usability thereof, including the applications for the digitization of government. The digitization of all government areas has been among the European Union's priorities since 2014. The objective is to create a fully operational unified
EU digital market. The European Commission has adopted the EU eGovernment Action Plan for 2016-2020. The aim of this action plan is the modernization of public administration, establishment of a unified digital market and increased involvement of citizens and businesses for the purposes of providing high quality services. The EU eGovernment Action Plan defines specific measures for the acceleration of implementation of the existing 
legislation and the transition to online public services.

As stated by Mates and Smejkal (2012), the aim of eGovernment and electronic communication is to provide private entities with greater comfort when contacting the state and other public authorities with modern digital tools, accelerating, simplifying the communication and streamlining internal processes of public authorities, leading to a greater accessibility of public administration and transparency towards citizens. Lidinský (2008) defines eGovernment as the use of information technology by public institutions in order to ensure exchange of information with the citizens, private organizations and other public institutions for the purposes of increasing the efficiency of internal operations and the provision of prompt, accessible and quality information services.

\section{Research Approach}

According to Grant and Chau (2006), the following three key activities can be identified within eGovernment: the development and provision of quality and integrated public sector services, implementation of efficient relationship management inside the individual departments, and support of economic and social development of citizens and enterprises both at the national and international levels.

According to Vaníček (2011), electronic communication is understood as the key component of eGovernment. This author distinguishes three elementary types of governmentcommunication channels Government-to-Citizen (G2C), Government-to-Business (G2B) and Government-to-Government (G2G).

E-participation systems intended for the consultations and dialogue between citizens and governments quite often do not achieve the expected goals and levels of implementation. In her study, Toots (2019) dealt with the Estonian e-participation portal Osale.ee. She concluded that e-participation systems face three-fold challenges: those typical to IS projects, those emerging from the public sector context, and specific challenges that emanate from the complex context of democratic participation.

For example, Nixon and Koutrakou (2007) pursued the issue of utilization of new possibilities in information and communication technologies in the provision of public services. They monitored the development of digital public administration and applications thereof throughout Europe and examined how the information and communication technologies affected political activities and processes. Authors Lindgrena et al. (2019) dealt with the question of how the digitization of public services affected the interaction between the citizens and their government. They identified several problematic areas and expressed ethical concerns in terms of responsibility and requalification of citizens and public officials, since the provision of public services was turning into the citizen's self-service.

Implementation of eGovernment is an ongoing development process. Different approaches to its implementation are studied for example by Strouhal (2019), who analysed the system of eGovernment regulations in selected EU countries in connection with the application of a decentralized or centralized approach. The development of eGovernment and the digitization of public administration has been monitored for a long time by the evaluation reports of the European Commission, which are composed and published as part of the ISA (Interoperability solutions for public administrations, businesses and citizens) programme in cooperation with the relevant national authorities (i.e., in case of the Czech Republic, the eGovernment Department at the Ministry of the Interior). These evaluation reports have been focusing on the development of eGovernment in individual European countries, including the Czech Republic, starting from 2014.

According to Pitić et al. (2019), tax administrations in the developed countries are entering the final phase of digitization, where the complete change of tax paradigm is the final goal. The topic of tax administration in the context of ensuring the security of tax data and the possible way of solving the digital transformation through international cooperation was examined for example by Romundset (2018) and Heikura (2018).

The new trends in the development of tax regimes, digitization of tax administration, electronic communication and analysis of the manner the cyber development impacts the ways and forms in which the public administration interacts with the citizens were discussed and published for example by Campbell and Hanschit (2018), Mingram and Grosselin (2016), and Vuković (2018). Crivelli (2019) evaluated key features of an efficient tax 
administration and their relative strengths and weaknesses. He proposed a simple index of tax administration strength, based on objective indicators reflecting key organizational and operational aspects of revenue administrations relative to international best practice.

The digitization of the tax administration concerned taxpayers and other tax-related professions. Knudsen (2020) identified three main differences in how IIS and digitalization have influenced accounting, and three concurrent avenues for future research on digitalization in accounting: the elusive boundaries of accounting, power relations, and knowledge production for decision-making. As stated Troshani et al. (2018) traditional businessto-government reporting is a core remit of the accounting function but is associated with a significant administrative burden on business. Their analyses illustrated how institutional work to develop digital business-to-government reporting across the jurisdictions was shaped by international influences and local factors. Public interest aroused also an impact of digitization on tax consulting. Frey and Osborne (2017) predicted that tax consulting would become obsolete. Authors Diller et al. (2020) examined the digitization efforts of German tax consultants. They stated that tax consultants scoring high on extraversion and openness to experience and low on neuroticism exhibit a higher level of digitization.

Tax administrations in all countries are trying to reduce administrative and compliance costs. Tax compliance costs tend to be disproportionately higher for small and young businesses. Dabla-Norris et al. (2020) examined how the quality of tax administration affects firm performance for a large sample of firms in emerging market and developing economies. Authors showed that better tax administration attenuated the productivity gap of small and young firms relative to larger and older firms. Electronic communication with tax administration means a fast, secure and cheap way of exchanging information without the limitations of geographical barriers. With the evolving advances in technology, it allows both authentic and secure transfer of information. The main benefits of digitization are in particular the speed of exchange of information, the possibility of filing 24 hours a day, 7 days a week, as well as financial savings (Budiš \& Hřebíková, 2010).
Authors Kumar and Gupta (2017) investigated income tax payer's perceptions toward electronic filing in India. Their results suggested that although E-filing has given ease of use to the income tax payers yet they are facing various problems like peak rush, difficulties in operations in this process. Pippin and Tosun (2014) analysed variables having a positive impact on e-filing rates in the USA. They found out significant variation in e-filing rates across and within states. E-filing rates were found to be lower in rural counties, counties with low population size, counties with a lower share of females and counties with a higher share of the elderly population. Gunter (2019) explored the relationship between Internet availability induced electronic filing on tax reporting behaviour. He found out suggestive evidence that e-filing driven by Internet access increased itemizing rates and lowered tax-to-income ratios in the USA. The results suggested changes in tax filing method driven by increased computer use and Internet access helped taxpayers identify relevant deductions and credits and lowered reported tax liability.

Digitization of financial administration is currently a very relevant and discussed topic, both on the international level as well as internally within the individual countries. This sector is being constantly improved and the group of entities able to communicate in the electronic form is constantly expanding. The motivation for our research was the fact that the Czech Republic has been ranking below the average among the EU countries in evaluation of eGovernment (e.g. it ranked 21st in the ranking of Digital Public Services in 2019). The objective of the research is to discover how taxpayers perceive and evaluate electronic filings for the Financial Administration. There is also a partial goal of evaluating the development of electronic filings for the Financial Administration.

\section{Digitization of Public Administration in the Czech Republic}

The main body responsible for the development of eGovernment and the digitization of public administration in the Czech Republic is the Ministry of the Interior, which also acts as a coordinator for the information and communication technologies. Competences for the public administration information systems 
were taken over by the Ministry of the Interior from the Ministry of Informatics, which was abolished in 2007. The Ministry of the Interior prepared the first strategic document for 20072013, the so-called Smart administration (SA) - Efficient Public Administration and Friendly Public Services.

During the period when the Smart administration was applicable, the following was implemented and executed:

- Czech POINT contact places since 2008;

- Data boxes since 2009;

- Basic registers, which have been used for the storing of basic referential data since 2012:

$\square$ Register of Persons;

$\square$ Population Register;

$\square$ Register of Rights and Obligations;

$\square$ Register of Territorial Identification, Addresses and Real Estates.

Czech POINT contact places have been allowing the citizens to obtain all data, copies and extracts kept in the central public records and registers about their person, property and rights. Data boxes have been enabling official communication of natural persons and legal entities with the public administration bodies in electronic form. It is mandatory for all authorities to communicate through data boxes with every entity that has one. It is a statutory obligation to establish a data box for all public authorities, legal entities registered in the Commercial Register, lawyers, tax advisors, and insolvency administrators.

Anew document called Strategic Framework for the Development of Public Administration in the Czech Republic for 2014-2020 was created for the new programme period. It defined additional topics for the modernization of public administration and eGovernment: the modernization of public administration, review and optimization of public administration performance within its territory, increasing public administration accessibility and transparency through eGovernment tools as well as the professionalization and development of human resources in public administration. The goal is to streamline the work of the authorities, to increase the transparency of public administration performance, to bring public services closer to the citizen and to ensure the quality thereof. The Government Council for the Information Society established in 2014 is the body of the Government of the Czech
Republic initiating and coordinating the sphere of the public administration reform, information society, digital agenda, eGovernment and information and communication technologies.

\section{Digitization of the Financial Administration in the Czech Republic}

Financial Administration is the part of the public administration the responsibilities of which include the direct and indirect taxes. The Financial Administration of the Czech Republic comprises a three-tier system of territorial financial authorities subordinated to the Ministry of Finance. In compliance with the EU legislative requirements, the Financial Administration of the Czech Republic is obliged to meet the requirements for the gradual digitization of taxes. The aim of the digitization is the improvement of accessibility and simplification of communication between the tax administrator and the taxpayer over the course of tax administration actions, procedures and proceedings.

With the introduction of modern information technologies, the Financial Administration of the Czech Republic has at its disposal an increasing number of communication channels. These can be used when obtaining information on the activities of the entities obliged to disclose such required information, or for the processing of the filings and requests thereof. The Financial Administration of the Czech Republic has been using the Automated Tax Information System (ADIS), a nationwide information system, since 1993. However, this system is already outdated at present, and there are weak points, such as slow and sometimes insufficient updates and incorporation of new changes in relation to the amending of laws. Tax Portal is the tool provided for the purposes of interaction with the Financial Administration and for the obtaining of information regarding the tax proceedings through Tax Information Box.

The actual breakpoint in the digital communication and the use thereof in real life for the Financial Administration was noticed in connection with the adoption of the Act No. 227/2000 Coll., on Electronic Signatures and on Amendment to Certain Related Acts. This amendment provided for the possibility of executing the filings for the Financial Administration in digital form, through the joint technical system of the tax administrators. The possibility of electronic communication regarding 
taxes resulted in the launch of the Tax Portal (Macková \& Štědroň, 2009). Act No. 12/2020 on the Right to Digital Services, Coll. gives citizens the right to communicate digitally with authorities and the authorities to solve their problems digitally with them. This Act is related to the adopted amendment to the Act on Banks (Act No. 49/2020 Coll. amending Act No. 21/1992 Coll., on Banks, as amended). The amendment creates conditions for the creation of the socalled banking identity. Identity is a simple and free form of access to e-government services.

At present, pursuant to Section 71 of the Act No. 280/2009 Coll., Tax Code, as last amended, it is possible to submit the filing in writing, in oral form into the protocol, or through a data message, which is undersigned in a manner which other laws connect with the effects of one's own signature (QES) or the verified identity of the sender by the way used to sign in to his/her data box (ISDB).

The Electronic filing for the Financial Administration (EPO) application on the Tax Portal or the electronic tax office My Taxes allow sending of documents in digital form through a digital filing office. For all entities who have data box or who have the statutory obligation to have their financial statements audited, it is obligatory to submit all filings solely remotely, through their data box. See Tab. 1 for the progress in the number of opened data boxes between 2009 and 2019. The highest increase in the growth can be seen in 2015 and 2016 . This is connected in particular with the VAT and the introduction of a control report.

The Electronic filing for the Financial Administration (EPO) application has a benefit, which is the check of correct calculation. This provides for the possibility to fix any errors even before the form is sent to the Financial Administration. This application also contains an interactive form with a bar code enabling to transfer the data from the tax return form to the relevant system, thus speeding up the processing thereof. Tax returns filled in this manner can be printed out and sent to the responsible Financial Administration office, or submitted through the Tax Portal, or a data box. The tax administrator receives digital filings to the joint technical system of the tax administrators, which operates as a digital filing office for the territorial financial authorities. After the filing has been received, a data message is sent immediately with an electronically signed filing delivery note for the purposes of proof of delivery, including the time of its receipt.

\section{Objective and Methods}

This article is discussing electronic filings for the Financial Administration in the Czech Republic. The objective of the research is to discover how taxpayers perceive and evaluate electronic filings for the Financial Administration. Their opinions were surveyed through the primary

Tab. 1: Cumulative number of data boxes opened in December in a given year

\begin{tabular}{c|c|c|c} 
Year & Number & Growth & Growth rate \\
\hline 2009 & 378,830 & & \\
\hline 2010 & 420,249 & 41,419 & 1.11 \\
\hline 2011 & 452,193 & 31,944 & 1.08 \\
\hline 2012 & 502,627 & 50,434 & 1.11 \\
\hline 2013 & 558,507 & 55,880 & 1.11 \\
\hline 2014 & 616,359 & 57,852 & 1.10 \\
\hline 2015 & 690,546 & 74,187 & 1.12 \\
\hline 2016 & 781,080 & 90,534 & 1.13 \\
\hline 2017 & 860,980 & 79,900 & 1.10 \\
\hline 2018 & 940,827 & 79,847 & 1.09 \\
\hline 2019 & $1,034,537$ & 93,710 & 1.10 \\
\hline
\end{tabular}

Source: using data retrieved January 11, 2020 from https://www.datoveschranky.info/statistiky 
research. There is also a partial goal of evaluating the development of electronic filings for the Financial Administration.

The tool used for the research was a questionnaire with close-ended as well as open-ended questions with no choice of given answers where the respondents could voice their opinion. A five-point Likert scale was utilized for the evaluation of the benefits of electronic filing. This scale allows not only finding out the content of the responder's opinion, but also its approximate rating strength. 1,350 entrepreneurs from the Czech Republic were contacted electronically, out of which $47.7 \%$ responded. A total of 644 questionnaires were included in the processing, 224 from natural persons (NP) and 420 from legal entities (LE). The respondents were divided according to the size of the company into micro, small, medium and large (Tab. 2). This table shows also the division by person who provides the electronic filling. The person authorized to interact with the Financial Administration is most frequently an external accountant.

The survey data was evaluated using the SPSS software. Its reliability was verified using the Cronbach's alpha scale, which is the most commonly used indicator of reliability. The Pearson chi-square test was selected to demonstrate the relations between qualitative data. Based on contingency tables of absolute and hypothetical values, the test criterion was calculated, expressed by the following formula:

$$
\chi_{P}^{2}=\sum_{i=1}^{r} \sum_{j=1}^{s} \frac{\left(n_{i j}-\varphi_{i j}\right)^{2}}{\varphi_{i j}}
$$

where $n_{i j}$ are absolute values and $\varphi_{i j}$ hypothetical.
The calculated $\chi_{P}^{2}$ value is then compared to the critical value $\chi_{1-\alpha}^{2}$ from the distribution table with degrees of freedom $d f=(s-1) \times(r-1)$ and chosen confidence level $\alpha=0.05$. If the calculated $\chi_{P}^{2}$ value $>$ critical $\chi_{1-\alpha}^{2}$ value, then we reject the null hypothesis. Cramer's $\mathrm{V}$ is a statistic used to measure the strength of dependence between two nominal variables.

The Kolmogorov-Smirnov test was used for the verification of normality of data and following the test results, non-parametric tests were used (since the data is not distributed normally). The hypotheses for two independent samples were verified by the Mann-Whitney test for independent samples from the joint distribution with the same dispersion and form. Figures were calculated based on the formula:

$$
U_{1}=\mathrm{n}_{1} \mathrm{n}_{2}+\frac{\mathrm{n}_{1\left(\mathrm{n}_{1}+1\right)}}{2}-\mathrm{T}_{1}
$$

where $\mathrm{T}_{1}$ is the sum of the ranks of values $X 1$, $X 2, \ldots, X n 1$.

The test criterion was determined according the formula:

$$
T(X, Y)=\min \left(U_{1} U_{2}\right)
$$

The calculated test criterion was compared with the critical value; if the test criterion is less than or equal to the critical value, then the null hypothesis is rejected.

Hypotheses for more independent samples were verified by the use of the Kruskal-Wallis test, assessing the homogeneity of median values of an explained variable. The tested statistics were calculated using the following formula:

\section{Tab. 2: Division of respondents to the size of the company and the person who provides the electronic filling}

\begin{tabular}{l|c|c|l|c|c}
\multicolumn{1}{c|}{ Company } & Frequency & Percent & \multicolumn{1}{c|}{ Person } & Frequency & Percent \\
\hline Micro & 356 & 55.3 & Entrepreneur & 110 & 17.1 \\
\hline Small & 104 & 16.1 & External accountant & 283 & 43.9 \\
\hline Medium & 92 & 14.3 & Internal accountant & 176 & 27.3 \\
\hline Large & 92 & 14.3 & Proxy & 42 & 6.5 \\
\hline Total & 644 & 100.0 & More people & 33 & 5.1 \\
\hline & & & Total & 644 & 100.0 \\
\hline
\end{tabular}


$Q=-3(\mathrm{n}+1)+\frac{12}{\mathrm{n}(\mathrm{n}+1)} \sum_{i=1}^{k} \frac{T_{i}^{2}}{n_{i}}-3(n+1)$

Null hypothesis $H_{0}$ is rejected at the a level of significance if the $Q$ test statistics are higher than the critical value at the respective a level of significance, so if $Q \geq \chi_{k-1}^{2}(\alpha)$ for small samples, it is necessary to compare the $\alpha$ statistics with tables for the Kruskal-Wallis test.

\section{Electronic Fillings - Results and Discussion}

Electronic communication is perceived as very important by the Czech Financial Administration, since it should result in the reduction of work for the territorial financial authorities. Even though the Electronic filing for the Financial Administration (EPO) has been improving, only a relatively small number of taxpayers took advantage of this option in the first years (Fig. 1). The main obstacle to the more common use of the EPO application was the fact that originals of some of the mandatory attachments to the tax return could not be sent electronically. Gradually, the obligation to submit some forms solely in electronic form was introduced. This obligation has been established for the VAT recapitulative statements since 2010 .

The EPO application was further modified in 2011 with the aim of increasing user comfort. The electronic Real estate tax form was converted to the new EPO application technology. In comparison to the previous year, in 2012 the number of electronic filings doubled. Increased interest of the public in the electronic filing in 2014 corresponds with the publication of new forms in the EPO application.

From January 1, 2015, the obligation to submit form filings electronically was introduced for all taxpayers who have a data box at their disposal or who have the statutory obligation to have their financial statements audited. These forms included the submission of an application for registration, a notification of change of registration data, a regular and additional tax returns, report and settlement.

The greatest increase in the number of electronic filings occurred in 2016 in connection with VAT. For one thing, as of January 1, 2016, a new statutory obligation to submit control reports has arisen for the payers, and these can only be filed electronically. And for another, the obligation to submit the rest of the forms related to the VAT (tax return, additional tax

\section{Fig. 1: Development of the electronic filings between 2008 and 2019}

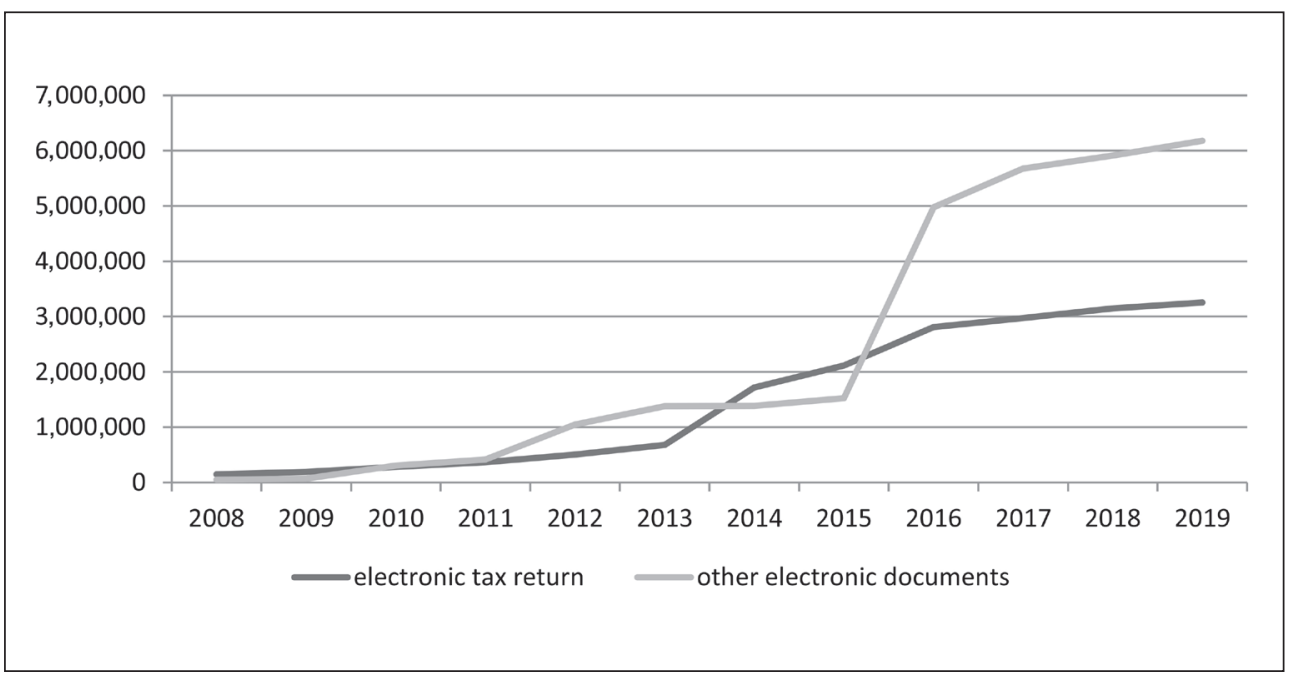

Source: own using data retrieved April 25, 2020, from http://www.financnisprava.cz/cs/dane-elektronicky/danovy-portal/pocty-podani-epo 
return, application for registration, etc) solely in electronic form was introduced for all payers with no exception, regardless if they are legal entities or natural persons.

Each year, the number of tax subjects using the electronic form for submitting their tax returns is rising. This way not only saves their time, it also contributes to a faster processing of tax returns. In connection with these new options of electronic communication, the Financial Administration was able to reduce the number of printed tax return forms issued directly at the office.

In case of an electronic communication, it is necessary to protect the obtained information in order not to lose its credibility. This means to own a qualified certificate (filing in with a qualified electronic signature - QES) or a data box (ISDB - filing in with the verified identity of the sender by the way used to sign in to their data box). It is also possible to execute the filing on the Tax Portal (Other filings electronic filing without QES or without ISDB). Such filing needs to be confirmed with a filing sent with a signature or through a data box, 5 days from the day of the receipt thereof by the tax administrator at the latest.
See Fig. 2 for the percentage of individual types of electronic filings between 2008 and 2019. In the beginning, there was a high rate of filings with QES. As late as in 2012, there can be seen a significant increase in electronic filings made without a qualified electronic signature (other filings), with a year-on-year increase of $250 \%$. This increase can be also contributed to an extending number of forms available in the EPO application on the Tax Portal. Other filings are also utilized by the subjects for which electronic filing of tax returns is not mandatory. They are using this way to meet the submitting deadline. For example in 2017 , over 260,000 income tax returns by individuals were submitted electronically. Out of which only 63,000 tax returns were sent with a qualified electronic signature (QES).

See Fig. 3 for the depiction of the share of electronically filed tax returns in the total number of filed tax returns by individual types of taxes. The VAT, road tax and corporate income tax have the highest share. The percentage of electronically filed returns is affected mainly by the law, since electronic filings were introduced as mandatory for some entities. The increasing share of electronically filed tax returns is

\section{Fig. 2: Development of electronic filings between 2008 and 2019}

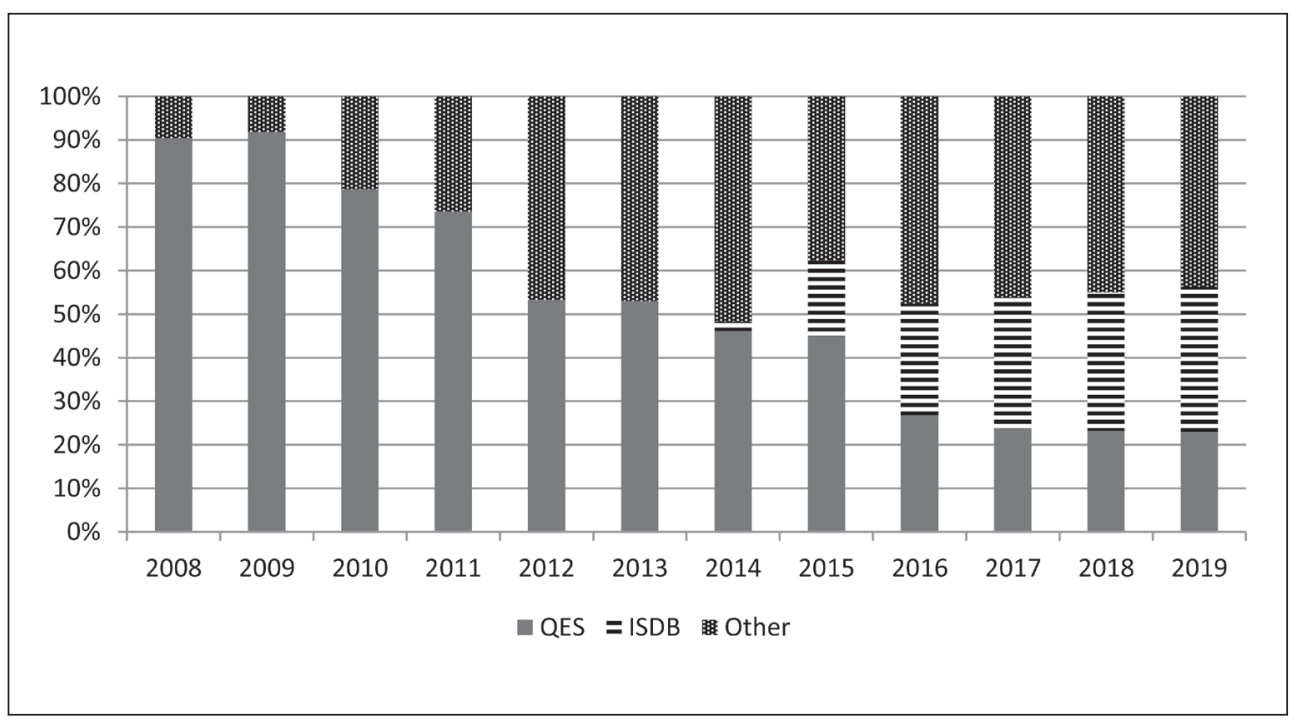

Source: own using data retrieved April 25, 2020, from http://www.financnisprava.cz/cs/dane-elektronicky/danovy-portal/pocty-podani-epo 


\section{Fig. 3: Development of electronic filings per type of tax between 2008 and 2019}

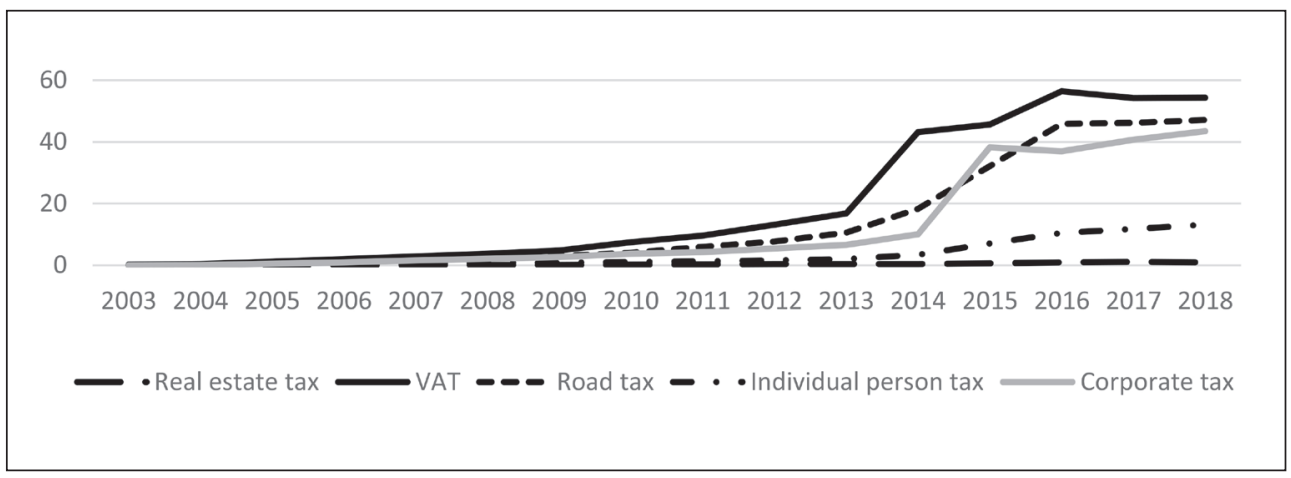

Source: own using data retrieved April 25, 2020, from http://www.financnisprava.cz/cs/dane-elektronicky/danovy-portal/pocty-podani-epo

positive for the Financial Administration, as it reduces the laboriousness of their processing.

\section{Evaluation of the Perception towards Benefits of Electronic Filing - Results and Discussion}

In the beginning, it had to be determined whether the choice of the person communicating with the Financial Administration (FA) depends on the form of business. The Pearson Chi-square test was used for the verification of the fact.

$\mathrm{H} 1_{0}$ : The choice of the person communicating with the tax authority does not depend on the form of business was established.

As seen in Tab. 3, it is evident that we reject this hypothesis. The strength of the dependency was tested with Cramer's V and the resulting value of 0.430 shows a medium dependency. Based on the results, in case of natural persons, it was discovered that the one who mainly interacts with the Financial Administration is an external accountant (130 respondents) or the entrepreneur personally (68 respondents). For legal entities, the person authorized to interact with the Financial Administration is most frequently an accountant (internal accountant 162 respondents and external accountant 153 respondents).

The way respondents perceive the benefits of electronic filing was determined with the help of the Likert scale. According to the data in Tab. 4 , it is clear that saving of time is considered as its biggest benefit (almost $84 \%$ of respondents agreed). The majority of respondents consider error checking as a great benefit as well

\begin{tabular}{|c|c|c|c|}
\hline $\begin{array}{l}\text { Relation betwee } \\
\text { of business }\end{array}$ & erson c & & FA and the form \\
\hline & Value & df & $\begin{array}{c}\text { Asymptotic significance } \\
\text { (2-sided) }\end{array}$ \\
\hline Pearson Chi-square ${ }^{a}$ & 118.862 & 4 & 0.000 \\
\hline Likelihood ratio & 132.414 & 4 & 0.000 \\
\hline Linear-by-Linear association & 85.248 & 1 & 0.000 \\
\hline $\mathrm{N}$ of valid cases & 644 & & \\
\hline
\end{tabular}

Source: own using data from questioners Note: ${ }^{a} 0$ cells $(0 \%)$ have expected count less than 5 . The minimum expected count is 11.48 . 
Tab. 4: Perception towards benefits of electronic filing

\begin{tabular}{l|c|c|c|c|c} 
& Agree & $\begin{array}{c}\text { Mostly } \\
\text { agree }\end{array}$ & Neutral & $\begin{array}{c}\text { Mostly } \\
\text { disagree }\end{array}$ & Disagree \\
\hline Availability of information & 256 & 196 & 154 & 16 & 22 \\
\hline Time savings & 410 & 130 & 92 & 4 & 8 \\
\hline Cost savings & 262 & 152 & 180 & 20 & 30 \\
\hline Error checking & 226 & 226 & 158 & 16 & 18 \\
\hline
\end{tabular}

Source: own using data from questioners

(68\% of respondents agreed). Regarding the cost saving, almost $30 \%$ of respondents expressed neutral opinion. Among these were mostly the entities on behalf of which an external accountant interacts with the Financial Administration. The most common answer by far, in terms of availability of information, time and cost savings was agreement. Error checking was not perceived as a benefit as definitely as the rest.

The investigation of differences in the perception towards benefits of electronic filing was executed from several aspects (form of business, size of the company and the person who performs the electronic filing). First, the reliability of the research tool was verified with the Cronbach's alpha indicator. The value of Cronbach's alpha equals 0.781 and indicates a sufficiently high reliability of the research tool.

Mann-Whitney test was used to verify whether the perception towards benefits of electronic filing is dependent of the form of business.

$\mathrm{H}_{2}$ : The perception towards benefits is independent from the form of business was established.
$\mathrm{H} 2_{0}$ has been rejected for all the cases, since the perception towards benefits depends on the form of business (Tab. 5). Legal entities see the electronic filing as more beneficial than natural persons. According to the answers given by the respondents, the accessibility of information is a benefit of the electronic communication for $75 \%$ of legal entities and $62 \%$ of natural persons. The use of electronic filing is connected with the saving of time for $92 \%$ legal entities, compared to only $69 \%$ natural persons. The percentage of respondents who see the saving of costs as a benefit is greater for the legal entities as well $(71 \%)$ it is only $52 \%$ for natural persons. Error checking is perceived as an electronic filing benefit by $77 \%$ of legal entities and $58 \%$ of natural persons. On the other hand, a greater percentage of natural persons expressed a neutral opinion, which could be connected to the more common utilization of external accounting services.

Due to a higher number of independent variables, a Kruskal-Wallis test was used to verify the rest of other hypotheses.

H3: The perception towards benefits is independent on the size of the company.

\section{Tab. 5: Relation of the perception between the benefits and the form of business}

\begin{tabular}{l|c|c|c|c} 
& $\begin{array}{c}\text { Availability } \\
\text { of information }\end{array}$ & Time savings & Cost savings & Error checking \\
\hline Mann-Whitney U & 39,996 & 33,942 & 35,448 & 36,278 \\
\hline Wilcoxon W & 128,406 & 122,352 & 123,858 & 124,688 \\
\hline Z & -3.311 & -6.813 & -5.441 & -5.048 \\
\hline Asymp. sig. (2-tailed) & 0.001 & 0.000 & 0.000 & 0.000 \\
\hline
\end{tabular}


$H 3_{0}$ has been rejected for all cases, since the perception towards benefits depends on the size of the company (Tab. 6). Availability of information is appreciated the most by the large companies, $85 \%$, and the least by the micro companies, $63 \%$. Time saving is seen as an electronic filing benefit by $94 \%$ of the larger companies as opposed to only $74 \%$ of micro companies. The majority of medium companies, $87 \%$, agrees with a benefit in the form of cost savings, while the micro companies agree the least, $55 \%$, as well as only $67 \%$ of the large companies. Mostly the medium sized companies, $85 \%$, and the least by the micro companies, $64 \%$, perceive error checking as an electronic filing benefit. According to our opinion, the filing of VAT forms can influence the respondents' views. Some of the smaller companies with lower turnover may use a quarterly tax period resulting in a smaller number of such filings. On the other hand, companies with a turnover above the defined limit must file in the VAT returns, control statement and recapitulative statement every month. The highest percentage of micro companies expressed a neutral opinion, which may be influenced by the fact that it is more common that an external accountant or a proxy interacts on behalf of the micro companies, and therefore the electronic form of communication may not present such a saving of time or costs for them.

Then, $\mathrm{H}_{4}$ : The perception towards benefits of electronic filing is independent on the person preparing the electronic filing for the Financial Administration.

$\mathrm{H} 4_{0}$ cannot be rejected when it comes to the perception towards benefits in form of the availability of information and error checking, i.e., this perception is independent on the person preparing the electronic filing (Tab. 7). The perception towards availability of information as a benefit stated by the respondents from the individual groups is ranging from $62 \%$ to $74 \%$. It is an interesting fact that the accountants, both external and internal, assess the accessibility of information as the greatest electronic filing benefit. For the perception towards error checking as a benefit, the variability is also quite small, ranging from $66 \%$ to $73 \%$. Almost $80 \%$ of internal accountants agree that error checking is an electronic filing benefit which could save them the time potentially spent with the correction thereof. Internal accountants are usually processing tax returns and submitting electronic filings in large companies, which means working with a greater amount of data, therefore, error checking may be more important for them.

\section{Tab. 6: Relation between the perception towards benefits and the size of the company}

\begin{tabular}{l|c|c|c|c} 
& $\begin{array}{c}\text { Availability } \\
\text { of information }\end{array}$ & Time savings & Cost savings & Error checking \\
\hline Kruskal-Wallis H & 22.698 & 46.290 & 23.276 & 22.441 \\
\hline df & 3 & 3 & 3 & 3 \\
\hline Asymp. sig. & 0.000 & 0.000 & 0.000 & 0.000 \\
\hline
\end{tabular}

Source: own using data from questioners

Tab. 7:

Relation between the perception towards benefits and the person who provides the electronic filing

\begin{tabular}{l|c|c|c|c} 
& $\begin{array}{c}\text { Availability } \\
\text { of information }\end{array}$ & Time savings & Cost savings & Error checking \\
\hline Kruskal-Wallis H & 4.346 & 14.715 & 1.894 & 9.397 \\
\hline df & 4 & 4 & 4 & 4 \\
\hline Asymp. sig. & 0.361 & 0.005 & 0.018 & 0.052 \\
\hline
\end{tabular}


$\mathrm{H} 4_{0}$ has been rejected when it comes to the perception towards the time and costs saving benefits, which means, the perception does depend on who prepares the electronic filing. The saving of time as an electronic filing benefit is perceived the most in the companies where it is prepared by internal accountants, $96 \%$, and the least in the companies where the entrepreneurs themselves are preparing the electronic filing, only $73 \%$. Due to the large amount of work, time saving is a very important aspect for the internal accountants. When it comes to entrepreneurs, the result may be affected by the fact that in case of more problematic and time-consuming filings, the interaction is transferred to another person, e.g., an external accountant.

Cost saving as an electronic filing benefit was perceived the most by the internal accountants, $78 \%$, and the least by external accountants and proxies, $57 \%$. The results of the research show that for the entrepreneurs, the perception towards cost saving is not seen as the most important aspect. The main reason may be the fact that entrepreneurs include the costs incurred in the tax-deductible costs, or that these expenses are relatively small compared to the other costs. A correlation was found between the saving of time and the saving of costs, where in case of electronic filings submitted by internal accountants; both savings were perceived as positive the most.

The last hypothesis was verifying whether the perception towards electronic filing changes in relation to time.

H5: The perception towards benefits is independent on the period over which the respondent has been using the electronic filing.

$\mathrm{H} 5_{0}$ has been rejected, therefore, the perception towards benefits depends on the length of time over which the electronic filing has been used (Tab. 8). The respondents interacting electronically for a longer time can see more benefits in this form of communication. This may indicate the fact that disadvantages of the electronic filing prevail over the benefits for the respondents who have been communicating in this way for a short time. This may be caused for example by the fact that they need to deal with the issues related to training of employees in the use of a new suitable software, with the opening of a data box, obtaining a qualified electronic signature, etc.

This result also reflects the fact that electronic communication is constantly improving and the number of filings that can be submitted electronically is rising. The Financial Administration built a new tax information system 'My Taxes' in order to support the automation of processes and streamlining the work of the Financial and Customs Administrations in the Czech Republic. The objective is to introduce a simplification of the tax administration process, to strengthen the legal certainty and to reduce administrative burden on the part of both the tax administrator and the tax subject in an environment with the maximum possible level of security provided.

Respondents were also asked for their personal opinions regarding the electronic filing with an open-ended question. It was found from the answers that the respondents who are using the electronic filing with the Financial Administration perceive a faster feedback, time flexibility, availability outside of working hours and the possibility of submitting the filings at the last minute as the greatest benefits. When interacting with the Financial Administration, they are not limited either by the authority's office hours, or by the Financial Administration staff's expertise. When a business entity executes the submission of the filing electronically, it has a certainty that it will be sent, according to the respondents' opinions. The respondents see

\begin{tabular}{|c|c|c|c|c|}
\hline $\begin{array}{l}\text { Relat } \\
\text { the e }\end{array}$ & $\begin{array}{l}\text { ween the perc } \\
\text { ic filing has be }\end{array}$ & $\begin{array}{l}\text { on towards be } \\
\text { used }\end{array}$ & its and the pe & d over which \\
\hline & $\begin{array}{l}\text { Availability } \\
\text { of information }\end{array}$ & Time savings & Cost savings & Error checking \\
\hline Kruskal-Wallis H & 23.415 & 38.376 & 39.698 & 26.480 \\
\hline df & 12 & 12 & 12 & 12 \\
\hline Asymp. sig. & 0.024 & 0.000 & 0.000 & 0.009 \\
\hline
\end{tabular}


more benefits in the availability of information on the Financial Administration website, in the clear arrangement and the archiving of communication.

According to the respondents' answers, the electronic filing provides immediate overview whether they meet their tax obligations resulting in significant saving of time and costs and the possibility of checks. The respondents also state that their accountants' expertise and flexibility has allowed the companies to adapt to electronic communication with the Financial Administration quickly. This also means the possibility of faster clarification of any potential shortcomings and more efficient interaction with the Financial Administration. The entrepreneurs also say that by solving all the topics with their external accountant electronically, they can dedicate their time more intensively to their business.

At the same time, based on the questionnaire survey, there were identified also some issues, which the entrepreneurs run into in connection with the introduction of electronic filing (Fig. 4). Among the most common issues mentioned by the respondents were the complications with obtaining information on the requirements associated with the electronic filing. Further, some issues associated with the need to familiarize themselves with the relevant software were identified. A smaller number of respondents mentioned problems with the Internet connection and the increase in expenses associated with the purchase of computer equipment. Sporadically, some respondents stated also other specific issues in connection with the technical equipment and software updates. Several respondents mentioned increased expenses in connection with the need to pay an external accountant or to provide training for their employees as well.

In their answers to an open-ended question, respondents mention low security and an increased risk of a third party getting their data among the disadvantages. The obligation to open a data box or to obtain a qualified electronic signature is perceived as another disadvantage. The limited amount of data in the data box is also an issue. Among other disadvantages listed by the respondents can be found also a frequent malfunction of the system, incompatibility with accounting programs and the obligation to update the certificate resulting in increased costs and loss of time, especially when starting with using the electronic filing. Further disadvantages stated include the illegibility of XML files during the send-off and the penalties for the filing in printed form. According to some of the respondents, one of the electronic filing disadvantages is also the loss of personal contact and curtness.

According to the results from the questionnaire survey, it is possible to say that more than half of the respondents welcomed the introduction of electronic filing. Among the benefits listed by the respondents are the saving of time and elimination of the need to submit the forms personally at the Financial Administration or the post office. They evaluate electronic filings as more flexible, faster,

\section{Fig. 4: The most common issues associated with the introduction of electronic filing}

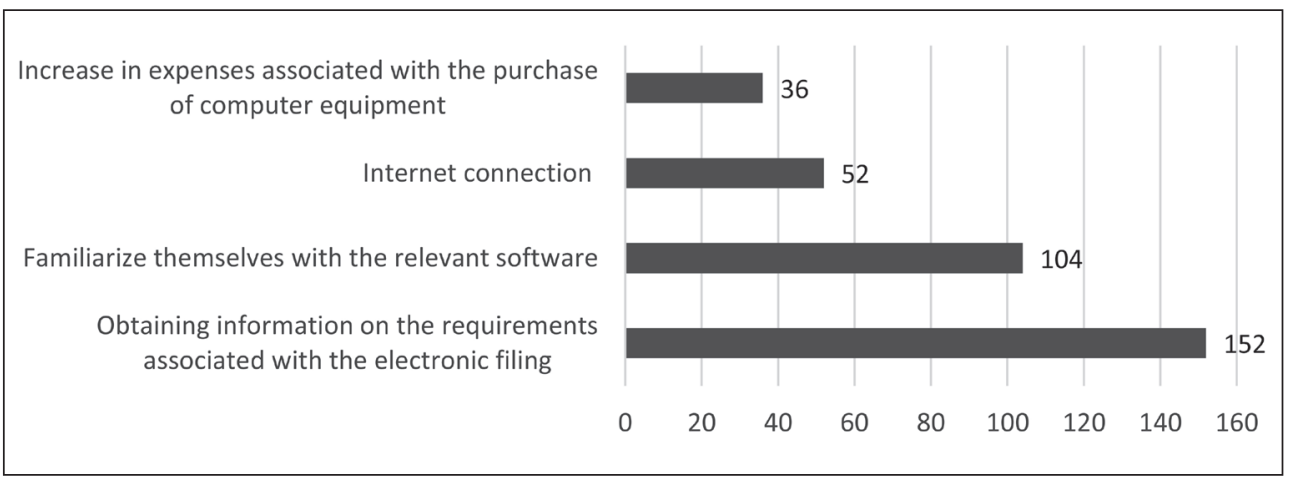


practical, mobile, simpler and more clearly arranged. The respondents further state that they are making their work easier and help to eliminate errors in the filings. This improves and speeds up the interaction with the Financial Administration.

The perception towards benefits of electronic filing was examined from several aspects; these include the form of business, size of the company and the person who performs the electronic filing. According to the respondents' answers, it was concluded that legal entities perceive the electronic filing as more beneficial compared to the natural persons. It was discovered that the perception towards benefits is dependent on the size of the company; micro companies see the least benefits in electronic filing. The check of errors was seen as significant in particular in the companies where internal accountants prepared the electronic filing, since it saves their time. From the time point of view, it can be said that the respondents using the electronic form for a longer period see more benefits in this form of communication.

\section{Conclusion}

Today, electronic communication presents a secure and efficient tool for the transfer of information. Its key benefits are the speed of the information transfer, the possibility of filing 24 hours a day, seven days a week, and the financial savings. In connection to the more frequent use of electronic filing by the taxpayers, the number of printed tax return forms has decreased. The laboriousness of the filing processing at the tax offices has been reduced too, which results in the gradual meeting of eGovernment goals.

One of the benefits of electronic filing is the automated calculation and error check. Saving of time and costs are among other significant benefits. The Tax Portal and the website put emphasis on the provision of information as well. Among the EPO benefits is also the possibility to use the provided instructions parallelly with the filling of the individual tax return lines. Some of the values are already predefined as well and the taxpayer no longer has to search for them in other sources (for example, coefficients for the real estate tax). One of the reasons for the growing interest of the public is also its easy availability outside working hours.
The perception towards benefits of electronic filing was examined from several aspects; these include the form of business, size of the company and the person who performs the electronic filing. According to the respondents' answers, it was concluded that legal entities perceive the electronic filing as more beneficial compared to the natural persons. It was discovered that the perception towards benefits is dependent on the size of the company; micro companies see the least benefits in electronic filing. The check of errors was seen as significant in particular in the companies where internal accountants prepared the electronic filing, since it saves their time. From the time point of view, it can be said that the respondents using the electronic form for a longer period see more benefits in this form of communication.

There were identified also some issues, especially regarding the obtaining of information on the requirements associated with the electronic filing and the familiarization with the relevant software. Some respondents mentioned also problems with Internet connection and the malfunction of the system. These issues, among others, are the topic of the Summary report on the digitization of public administration in the Czech Republic (Supreme Audit Office of the Czech Republic, 2019). Here, the government organizational bodies are being reproached for the insufficient pace of modernization of the public administration key information systems, since their current state is technologically limiting the development of eGovernment and the digitization of public administration. One of the solutions for the Financial Administration could be the replacement of the outdated ADIS with a new system meeting the current requirements for the electronic communication.

Regarding the client approach of the Financial Administration to the taxpayers, the Internet application for the Electronic Filing of Documents (EPO) is modified and improved every year. This application has no longer increased demands on the computer technology as in the beginnings, on the contrary, it allows filling in the forms in different browsers. It can be found on the Tax Portal of the Czech Financial Administration. The Financial Administration has built a new tax information system 'My Taxes', i.e., on modern and easy taxes for the citizens and entrepreneurs alike, which should 
bring a simpler tax system while supporting the automation of processes and streamlining the work of the Financial and Customs Administrations in the Czech Republic. The objective is to simplify the tax administration process, to strengthen legal certainty and to reduce both administrative and compliance costs.

Acknowledgments: "This paper was supported by the Ministry of Education, Youth and Sports Czech Republic within the Institutional Support for Long-term Development of a Research Organization in 2020."

\section{References}

Budiš, P., \& Hřebíková, I. (2010). Datové schránky: fungování, doručování, bezpečnost, návody. [Data boxes: operation, delivery, security, instructions]. Olomouc: ANAG.

Campbell, D. F. J., \& Hanschitz, G., C. (2018). Digitalization of Tax: Epistemic Tax Policy. In E. Carayannis, D. Campbell, \& M. Efthymiopoulos (Eds.), Handbook of Cyber-Development, Cyber-Democracy, and Cyber-Defense. Cham: Springer. https://doi. org/10.1007/978-3-319-06091-0_30-1

Crivelli, E. (2019). A basic tool to assess tax administration strength in emerging Europe. Economics of Transition and Institutional Change, 27(2), 425-446. https://doi.org/10.1111/ ecot. 12204

Dabla-Norris, E., Misch, F., Cleary, D., \& Khwaja, M. (2020). The quality of tax administration and firm performance: evidence from developing countries. International Tax Public Finance, 27(3), 514-551. https://doi. org/10.1007/s10797-019-09551-y

Diller, M., Asen, M., \& Späth, T. (2020). The effects of personality traits on digital transformation: Evidence from German tax consulting. International Journal of Accounting Information Systems, 37, 100455. https://doi. org/10.1016/j.accinf.2020.100455

European Commission. (2020). The Digital Economy and Society Index (DESI). Retrieved June 19, 2020, from https://ec.europa.eu/ digital-single-market/en/digital-economy-andsociety-index-desi

Frey, C. B., \& Osborne, M. A. (2017). The future of employment: how susceptible are jobs to computerisation? Technological Forecasting and Social Change, 114, 254-280. https://doi. org/10.1016/j.techfore.2016.08.019
Grant, G., \& Chau, D. (2005). Developing a Generic Framework for e-Government. Journal of Global Information Management, 13(1), 1-30. https://doi.org/10.4018/jgim.2005010101

Gunter, S. R. (2019). Your biggest refund, guaranteed? Internet access, tax filing method, and reported tax liability. International Tax Public Finance, 26(3), 536-570. https://doi. org/10.1007/s10797-018-9528-x

Heikura, M. (2018). Digital transformation challenges and possible solutions through international cooperation. In Impact of digitalisation on the transformation of tax administrations (pp. 10-12). Budapest: IOTA. Retrieved May 15, 2020, from https://www.iotatax.org/sites/default/files/publications/public_ files/impact-of-digitalisation-online-final.pdf

Knudsen, D. R. (2020). Elusive boundaries, power relations, and knowledge production: A systematic review of the literature on digitalization in accounting. International Journal of Accounting Information Systems, 36, 100441. https://doi.org/10.1016/j.accinf.2019.100441

Kumar, S., \& Gupta, S. (2017). A Study on Income Tax Payers Perception towards Electronic Filing. Journal of Internet Banking and Commerce, 22(7). Retrieved May 12, 2020, from https://www.icommercecentral.com/ peer-reviewed/a-study-on-income-tax-payersperception-towards-electronic-filing-85520.html

Lidinský, V., Švarcová, I., Budiš, P., Loebl. Z., \& Procházková, B. (2008). EGovernment bezpečně [EGovernment safely]. Prague: Grada.

Lindgren, I., Østergaard Madsen, C., Hofmann, S., \& Melin, U. (2019). Close encounters of the digital kind: A research agenda for the digitalization of public services. Government Information Quarterly, 36(3), 427436. https://doi.org/10.1016/j.giq.2019.03.002

Macková, A., \& Štědroň, B. (2009). Zákon o elektronických úkonech a autorizované konverzi dokumentů $\mathrm{s}$ komentářem [Act on Electronic Acts and Authorized Conversion of Documents with Commentary]. Prague: Wolters Kluwers.

Mates, P., \& Smejkal, V. (2012). E-government $v$ České republice: právní a technologické aspekty [E-government in the Czech Republic: legal and technological aspects]. Prague: Leges.

Mingram, A., \& Grosselin, T. (2016). Mexico initiates electronic audits. At the intersection of international tax and digital transformation. Just- 
in-time taxation. Retrieved May 12, 2020, from https://www.ey.com/Publication/vwLUAssets/ EY_GTW_Just_in_time_taxation_Final/\$FILE/ EY_GTW_Just_in_time_taxation_Final.pdf

Ministry of the Interior of the Czech Republic. (2016). Strategický rámec rozvoje veřejné správy České republiky pro období 2014-2020 [Strategic Framework for the Development of Public Administration in the Czech Republic for 2014-2020]. Retrieved May 20, 2020, from https://www.mvcr.cz/clanek/strategicky-ramecrozvoje.aspx

Nixon, P. G., \& Koutrakou, N. V. (2007). E-government in Europe: Re-booting the state. London: Routledge. https://doi. org/10.4324/9780203962381

Pippin, S., \& Tosun, M. (2014). Electronic Tax Filing in the United States: An Analysis of Possible Success factors. Electronic Journal of e-Government, 12(1), 22-38. https://academicpublishing.org/index.php/ejeg/article/ download/591/554

Pitić, G., Radosavljević, G., Babin, M., \& Erić, M. (2019). Digitalization of the tax administration in Serbia. Economika preduzeca, 67(1-2), 131-145. https://doi.org/10.5937/ EkoPre1808131P

Romundset, G. H. (2018). The Norwegian tax administration's strategy and experience with the use of new international standards in exchange of information. In Improving tax governance and ensuring data security. Budapest: IOTA. Retrieved April 22, 2020, from https://www.iota-tax.org/sites/default/ files/publications/public_files/improving-taxgovernance-and-ensuring-data-security.pdf
Strouhal, J. (2019). Regulace e-Governmentu v Evropské unii [Regulation of e-Government in the European Union]. In M. Bokša (Ed.), Digitální Česko v digitální Evropě (pp. 97-117). Mladá Boleslav: Škoda Auto University. Retrieved April 20, 2020, from https://www.vlada.cz/assets/evropskezalezitosti/aktualne/Digitalni_Cesko

Supreme Audit Office of the Czech Republic. (2019). Souhrnná zpráva o digitalizaci veřejné zprávy $v$ ČR [Summary report on the digitization of public administration in the Czech Republic]. Retrieved April 15, 2020, from https:// www.nku.cz/assets/publikace-a-dokumenty/ ostatni-publikace/zprava-o-digitalizaci-verejnespravy.pdf

Toots, M. (2019). Why E-participation systems fail: The case of Estonia's Osale.ee. Government Information Quarterly, 36(3), 546559. https://doi.org/10.1016/j.giq.2019.02.002

Troshani, I., Janssen, M., Lymer, A., \& Parker, L. D. (2018). Digital transformation of businessto-government reporting: An institutional work perspective. International Journal of Accounting Information Systems, 31, 17-36. https://doi. org/10.1016/j.accinf.2018.09.002

Vaníček, Z. (2011). Právní aspekty eGovernmentu $v$ ČR [Legal aspects of eGovernment in the Czech Republic]. Prague: Linde.

Vuković, M. (2018). Towards the Digitization of Tax Administration. Retrieved April 15, 2020, from https://www.cef-see.org/files/Digitization_ Tax_Administration.pdf 